\title{
Pengembangan instrumen pembelajaran fisika dengan model penemuan terbimbing berbantuan simulasi interaktif dan dampaknya terhadap keterampilan proses sains siswa
}

\author{
Mutahharah Hasyim \\ Pendidikan Fisika, Universitas Negeri Makassar, Indonesia \\ Surat-e: Muthahharah@unm.ac.id
}

\author{
Ahmad Swandi \\ Pendidikan Fisika, Universitas Bosowa, Indonesia \\ Surat-e: ahmad.swandi@universitasbosowa.ac.id
}

\section{Sri Rahmadhanningsih}

Fisika, Institut Teknologi Bandung, Indonesia

Surat-e: rahmadhanningsih@gmail.com

\section{Muhammad Taqwin}

Pendidikan Fisika, Universitas Pancasakti Makassar, Indonesia

Surat-e: taqwin@unpacti.ac.id

\section{Sparisoma Viridi}

Sains Komputasi, Institut Teknologi Bandung, Indonesia

Surat-e: dudung@fi.itb.ac.id

\begin{abstract}
Abstrak. Penelitian ini bertujuan untuk mengembangkan perangkat pembelajaran dengan Guided Discovery Model Assisted by Interactive Simulation (GDM-IS) untuk mengidentifikasi dampaknya terhadap keterampilan proses sains siswa pada konsep fluida statis. Penelitian ini menggunakan metode pengembangan 4D untuk menghasilkan perangkat pembelajaran namun hanya dilakukan 3 tahap yaitu Define, Design, dan Development. Pada tahapan development, dilakukan validasi terhadap perangkat pembelajaran GDM-IS yang telah dikembangkan yang meliputi RPP, Lembar Kerja Peserta Didik (LKPD), Media Pembelajaran serta lembar pengamatan keterampilan proses sains. Uji coba terbatas menggunakan desain penelitian One Shoot Case Study. Dalam desain ini instrumen pembelajaran yang telah dikembangkan digunakan dalam satu kelas sebagai sampel sebanyak 38 peserta didik. Data keterampilan proses sains diambil melalui observasi oleh dua orang pengamat. Berdasarkan analisis hasil validasi penilaiant terdadapi RPP, LKPD dan media berada pada persentasi diatas $80 \%$ yang masuk dalam kategori valid (baik). Selain itu data keterampilan proses desain siswa berada pada persentase di atas $80 \%$ dengan kategori sangat.
\end{abstract}

Kata kunci: GDM-IS, Keterampilan Proses Sains

\begin{abstract}
This study aims to develop a learning tool with Guided Discovery Model Assisted by Interactive Simulation (GDM-IS) to identify its impact on students' science skills processes on the concept of statistical fluids. This research uses the 4D development method to produce learning tools, but only 3 stages are carried out, namely Define, Design, and Development. At the development stage, validation is carried out on the GDM-IS learning tools that have been developed which include RPP, Student Worksheets (LKPD) and Learning Media. Limited trial using the One Shoot Case Study research design. The learning instrument design that has been developed in one class is a sample of 38 students. The process of science data skills is taken through observation by two observers. Based on the analysis of the results of the validation of the assessment against RPP, student worksheets and media are at a percentage above $80 \%$ which is included in the valid (good) category. In addition, the data on the design process skills of students were in the proportion above $80 \%$ in the very category.
\end{abstract}

Keywords: GDM-IS, Science Process Skill 


\section{Pendahuluan}

Sebagai salah satu bagian dari ilmu pengetahuan, fisika merupakan mata pelajaran yang memiliki peran penting dalam menunjang ilmu pengetahuan dan teknologi. Hal tersebut menuntut manusia untuk terus meningkatkan ilmu pengetahuan dan inovasi terkini terkait fisika. Begitu pula dengan tuntutan peserta didik untuk lebih mudah memahami konsep yang berkaitan dengan fisika, mereka ingin fisika diajarkan dengan cara yang tidak monoton, membosankan dan sulit dipahami serta mampu meningkatkan penguasaan konsepnya [1][2]. Oleh karena itu, peran guru sangat penting untuk merancang pembelajaran yang lebih menitikberatkan pada penguasaan konsep Fisika. Guru tidak hanya mengajar di depan kelas, tetapi juga perlu mengetahui apakah proses pembelajaran berjalan dengan baik atau tidak dan tujuan pembelajaran yang ingin dicapai tercapai secara maksimal atau tidak. Keterampilan guru fisika dalam mengembangkan perangkat pembelajaran fisika yang interaktif dan menarik sangat dibutuhkan.

Berdasarkan observasi yang dilakukan peneliti, pada umumnya dalam proses pembelajaran di kelas banyak guru yang sering tidak mengikuti langkah pembelajaran yang sebenarnya, sehingga proses pembelajaran tidak berjalan dengan baik dan tujuan pembelajaran tidak tercapai secara maksimal. Hal tersebut berdampak pada rendahnya penguasaan konsep fisika peserta didik dan motivasi belajar sangat kurang dikarenakan proses pembelajaran yang kurang menarik. Untuk menunjang pembelajaran yang baik, guru diharapkan mampu merancang perangkat pembelajaran yang dapat menggambarkan dengan jelas isi yang akan diberikan kepada peserta didik, sehingga dapat terjadi perubahan kompetensi pada diri siswa sendiri terhadap materi yang disajikan. Pembelajaran juga masih lebih bersifat Teacher Center, guru mendominasi proses pembelajaran dari awal hingga akhir, siswa jarang diminta untuk berpartisipasi, guru kurang dilibatkan dalam menggali pemikiran dan gagasan siswa, meminta siswa untuk menelaah lebih dalam konsep-konsep yang diberikan dan menampilkan fenomena fisika yang lebih nyata dalam kehidupan sehari-hari. Instrumen pembelajaran dalam pembelajaran yang digunakan juga sangat kurang dan kurang interaktif sehingga suasana pembelajaran kurang nyaman dan menyenangkan.

Perubahan kurikulum pendidikan di Indonesia dari Kurikulum Tingkat Satuan Pendidikan ke Kurikulum 2013 berdampak besar pada proses pembelajaran yang berlangsung di dalam kelas. Kurikulum 2013 merupakan kurikulum yang menekankan pada pola pembelajaran yang berpusat pada siswa, sedangkan guru hanya berperan sebagai fasilitator [3]. Dalam pelajaran Fisika di Sekolah Menengah Atas (SMA) dan sesuai dengan kurikulum yang berlaku, siswa ditekankan untuk menyelesaikan masalah dan bertindak (mengamati dan bereksperimen) secara mandiri. Oleh karena itu, guru perlu memperluas pengetahuan dan penalaran siswanya dengan menemukan hal-hal baru berupa pengalaman belajar. Berdasarkan Permendikbud No. 65 tahun 2014 tentang standar proses [3], model pembelajaran yang diutamakan dalam implementasi kurikulum 2013 adalah model pembelajaran inkuiri, model pembelajaran discovery, model pembelajaran berbasis proyek dan model pembelajaran berbasis masalah. Dalam Model Penemuan Terbimbing guru memberikan kesempatan kepada peserta didik untuk menjadi pemecah masalah atas permasalahan yang dihadapi secara mandiri, sehingga pengetahuan yang diperoleh peserta didik menjadi lebih personal, mudah diingat dan bertahan dalam jangka waktu yang lama [4]-[7]. Pembelajaran dengan Model Penemuan Terbimbing dapat berlangsung efektif bila guru menyiapkan instrumen pembelajaran yang sesuai.

Dalam menerapkan Model Guided Discovery, guru dapat menggunakan berbagai metode dalam pembelajaran seperti metode eksperimen dan metode demonstrasi untuk menunjukkan konsep fisika nyata sesuai dengan kehidupan sehari-hari [8]. Namun demikian masih banyak guru dan sekolah yang masih mengalami kendala dalam melaksanakan proses eksperimen seperti kekurangan bahan, peralatan, ruang laboratorium dan berbagai kendala lainnya [9], [10]. Berbagai solusi telah dikenalkan oleh beberapa penelitian sebelumnya untuk mengatasi masalah tersebut yaitu penggunaan berbagai teknologi untuk mendemonstrasikan atau mendemonstrasikan konsep fisika. Seperti yang pernah dilakukan oleh Swandi dkk, yang menggunakan bahan ajar interaktif berbasis simulasi komputer yang dapat meningkatkan hasil belajar siswa SMA [11]. Ada pula penelitian yang dilakukan oleh Palloan yang menggunakan simulasi komputer melalui aplikasi Excell pada materi kelistrikan magnet yang dapat meningkatkan pemahaman konseptual siswa [11], [12].

Para ahli pendidikan memandang fisika tidak hanya terdiri atas fakta, konsep dan teori yang dapat dihafalkan, tetapi juga terdiri atas kegiatan atau proses aktif menggunakan pikiran dan sikap ilmiah dalam mempelajari gejala alam yang belum dapat diterangkan [13]. Fisika sebagai ilmu yang terdiri dari produk dan proses. Produk fisika terdiri atas fakta, konsep, prinsip, prosedur, teori, hukum dan postulat. Semua itu 
merupakan produk yang diperoleh melalui serangkaian proses penemuan ilmiah melalui metode ilmiah yang didasari oleh sikap ilmiah. Keterampilan proses sains adalah keterampilan-keterampilan yang dipelajari siswa pada saat melakukan inkuiri ilmiah. Keterampilan proses sains adalah keterampilan yang dapat dilakukan siswa dalam kegiatan belajar mengajar, seperti pengamatan, pengklasifikasian, penginferensian, peramalan, pengkomunikasian, pengukuran, penggunaan bilangan, penginterpretasian data, melakukan eksperimen, pengontrolan variabel, perumusan hipotesis, pendefinisian secara operasional, dan perumusan model. Oleh karena itu, pembelajaran fisika sebaiknya juga dilakukan dengan kegiatan laboratorium.

Permasalahan ketersediaan sarana laboratorium disekolah dapat diantiasipasi dengan penggunaan teknologi simulasi. Saat ini ketersediaan simulasi komputer untuk pembelajaran sangat besar dan bisa kita dapatkan di internet. Namun tidak semua simulasi dapat digunakan secara langsung dalam pembelajaran. Simulasi tersebut perlu dikembangkan kembali oleh guru agar sesuai dengan konsep dan kurikulum yang berlaku. Guru juga perlu mengembangkan model pembelajaran yang sesuai dengan simulasi agar dapat digunakan secara mandiri oleh siswa. Sehingga diharapkan pembelajaran dengan bahan ajar berbasis teknologi simulasi dapat membuat siswa lebih aktif. Salah satu bahan ajar yang memenuhi kriteria tersebut disebut simulasi interaktif berbasis pembelajaran aktif [9]. Tujuan utama dari jenis simulasi ini adalah adalah membuat format pembelajaran yang melibatkan siswa dalam mempelajari fisika dan hal-hal yang berkaitan dengan teknologi lebih dalam sehingga mereka dapat memperoleh pemahaman yang lebih menyeluruh tentang konten yang dipelajari, baik secara konseptual maupun analitik [14]. Pemanfaatan simulasi interaktif mengintegrasikan perkuliahan, pemecahan masalah, dan kegiatan laboratorium langsung dengan teknologi [15]-[17][18]. Dengan penggunaan simulasi interaktif dengan metode eksperimen diharapkan berdampak positif pada keterampilan proses sains, keterampilan pemecahan masalah dan hasil belajar peserta didik [9], [19][20].

Berdasarkan hal tersebut peneliti mengembangkan instrumen pembelajaran Guided Discovery Model Assited Interactive Simulation (GDM-IS) yang diharapkan dapat meningkatkan hasil belajar siswa. Instrumen pembelajaran terdiri dari Rencana Pelaksanaan Pembelajaran (RPP), Buku Siswa (BS), Lembar Kegiatan Siswa (LKPD) dan Rencana Evaluasi (RE). Berdasarkan uraian di atas, maka peneliti melakukan penelitian pengembangan yang bertajuk "Pengembangan Instrumen Pembelajaran Fisika Dengan Model Penemuan Terbimbing Berbantuan Simulasi Interaktif dan Dampaknya terhadap Keterampilan proses Sains“.

\section{Metode Penelitian}

Jenis penelitian ini adalah penelitian pengembangan. Menurut Seels \& Richey dalam Hobri, penelitian pengembangan yang berorientasi pada pengembangan produk pada proses pengembangan perangkat pembelajaran dijelaskan selengkap mungkin dan produk akhir dievaluasi [21]. Dalam penelitian ini dikembangkan dalam bentuk perangkat pembelajaran yang meliputi RPP, Lembar Kerja Siswa, dan Lembar Pengamatan Keterampilan Proses Sains.

Dalam penelitian ini digunakan model pengembangan Thiagarajan dan Semmel. Model Thiagarajan terdiri dari empat tahap yang dikenal sebagai model 4-D [22] namun karna keterbatasan waktu dan biaya maka hanya dilakukan tiga tahap. Ketiga tahap tersebut adalah tahap pendefinisian, tahap desain, dan tahap pengembangan. Tahap pendefinisian bertujuan untuk mendefinisikan kebutuhan pembelajaran dengan menganalisis tujuan dan batasan materi. Tahap pendefinisian terdiri dari lima tahapan yaitu: analisis awalakhir, analisis peserta didik, analisis konsep, analisis tugas dan spesifikasi tujuan pembelajaran. Tahap perancangan bertujuan untuk merancang rancangan awal perangkat pembelajaran. Pada tahap ini terdapat empat kegiatan desain yaitu: penyusunan tes, pemilihan media, pemilihan format, dan desain awal pembelajaran. Tujuan tahap pengembangan adalah menghasilkan draf revisi instrumen pembelajaran dan revisi media. Langkah-langkah pada tahap ini adalah validasi pakar, revisi produk dan uji coba produk. Uji coba produk di lakukan di salah satu sekolah menengah atas di Makassar pada tahun ajaran 2019/2020. Desain uji coba menggunakan One Shoot Case Study . Pada desain ini terdapat 1 kelas sebagai sampel yang diambil dari populasi kelas X. Dari hasil tahapan uji coba diperoleh berbagai data yang selanjutnya digunakan untuk menganalisis kembali perangkat pembelajaran. Tahap penyebaran merupakan proses pengemasan perangkat yang siap disebarluaskan dan digunakan oleh guru dan peserta didik secara luas.

Instrumen yang digunakan dalam penelitian ini adalah lembar validasi perangkat pembelajaran, kuesioner evaluasi ahli media, evaluasi ahli materi, lembar penilaian keterampilan proses sains peserta didik. 
Data yang diperoleh dari penilaian ahli, dianalisis dengan melakukan coding, kemudian dideskripsikan secara kualitatif dan penggambaran data secara kontinum untuk mengetahui kategori penilaian. Teknik analisis data yang digunakan dalam penelitian ini adalah analisis deskriptif yakni dengan cara menghitung persentasi nilai hasil validasi [23]. Menurut Agustina, tingkat kelayakan produk hasil penelitian pengembangan diidentikkan dengan presentasi skor. Semakin besar presentasi skor hasil analisis data maka semakin baik tingkat kelayakan produk hasil penelitian pengembangan tersebut [23]. Kriteria dalam mengambil keputusan dalam validasi media simulasi fisika dengan VBA Excel dapat dilihat pada tabel dibawah ini [23].

Tabel 1. Kriteria Kelayakan Media Simulasi Fisika dengan VBA Excel

\begin{tabular}{lll}
\hline No & Persentase $\%$ & Keterangan \\
\hline 1 & $80-100$ & Baik/Valid \\
\hline 2 & $60-79,99$ & Cukup Baik/Cukup Valid \\
\hline 3 & $50-59,99$ & Kurang Baik/Kurang Valid \\
\hline 4 & $0-49,99$ & Tidak Baik (diganti) \\
\hline
\end{tabular}

Untuk melihat bagaimana level keterampilan proses sains peserta didik dilakukan pengamatan oleh 2 pengamat. Kemudian dianalisis untuk menentukan persentasi aspek keterampilan pemecahan masalah pada masing-masing unit. Adapun penentuan kriteria keterampilan proses sains sesuai pada tabel 2 [14], [24].

Tabel 2. Kriteria Keterampilan Proses Sains Peserta Didik

\begin{tabular}{lll}
\hline No & Persentase $\%$ & Keterangan \\
\hline 1 & $76-100$ & Sangat Baik \\
\hline 2 & $51-75$ & Baik \\
\hline 3 & $26-50$ & Kurang \\
\hline 4 & $0-25$ & Sangat Kurang \\
\hline
\end{tabular}

\section{Hasil Penelitian dan Pembahasan}

Rencana Pelaksanaan Pembelajaran disusun untuk lima kali pertemuan dengan alokasi waktu masingmasing $3 \times 45$ menit sesuai dengan beban belajar siswa SMA yang tertuang dalam struktur isi Kurikulum 2013 . RPP yang dikembangkan meliputi: (1) identitas mata pelajaran, meliputi: nama satuan pendidikan, nama mata pelajaran, kelas dan semester, pertemuan, alokasi waktu, (2) standar kompetensi, (3) kompetensi dasar, (4) indikator, (5)) tujuan pembelajaran, (6) metode pembelajaran, (7) skenario pembelajaran, (8) sumber dan instrumen pembelajaran, (9) penilaian.

Lembar Kerja Peserta Dididk (LKPD) dirancang untuk mengarahkan siswa melakukan pembelajaran sesuai dengan langkah-langkah pembelajaran dalam RPP yang disesuaikan dengan sintaks pembelajaran model pembelajaran penemuan terbimbing. Dalam LKPD peserta didik diberikan kondisi tertentu yang berkaitan dengan masing-masing unit. Siswa kemudian diarahkan untuk melihat tayangan simulasi di komputer, membaca dan memahami kondisi dalam LKPD yang diberikan kemudian membuat masalah sesuai dengan itu, membuat hipotesis, melakukan pengamatan kembali dengan media simulasi interaktif dan selanjutnya melakukan analisis serta menguji hipotesis yang dibuat berdasarkan hasil analisis. LKPD juga dilengkapi dengan beberapa contoh pelatihan mandiri untuk mencapai indikator yang telah dibuat.

Selanjutnya media pembelajaran (video dan simulasi) yang dikembangkan dengan menggunakan Lectora berisi: (1) Tujuan Pembelajaran, (2) Ringkasan Materi, (3) simulasi yang diambil dari www.youtube.com dan Phet Interactive Simulations, (3) Petunjuk merumuskan masalah, hipotesis, analisis dan kesimpulan. RPP, buku dan LKPD juga dapat diunduh secara langsung dengan mengklik menu "unduh" pada tampilan awal media pembelajaran komputer. Contoh tampilan buku dan LKPD. Berikut adalah salah satu video dan simulai interaktif pada konsep fluida statis sebagai berikut: 

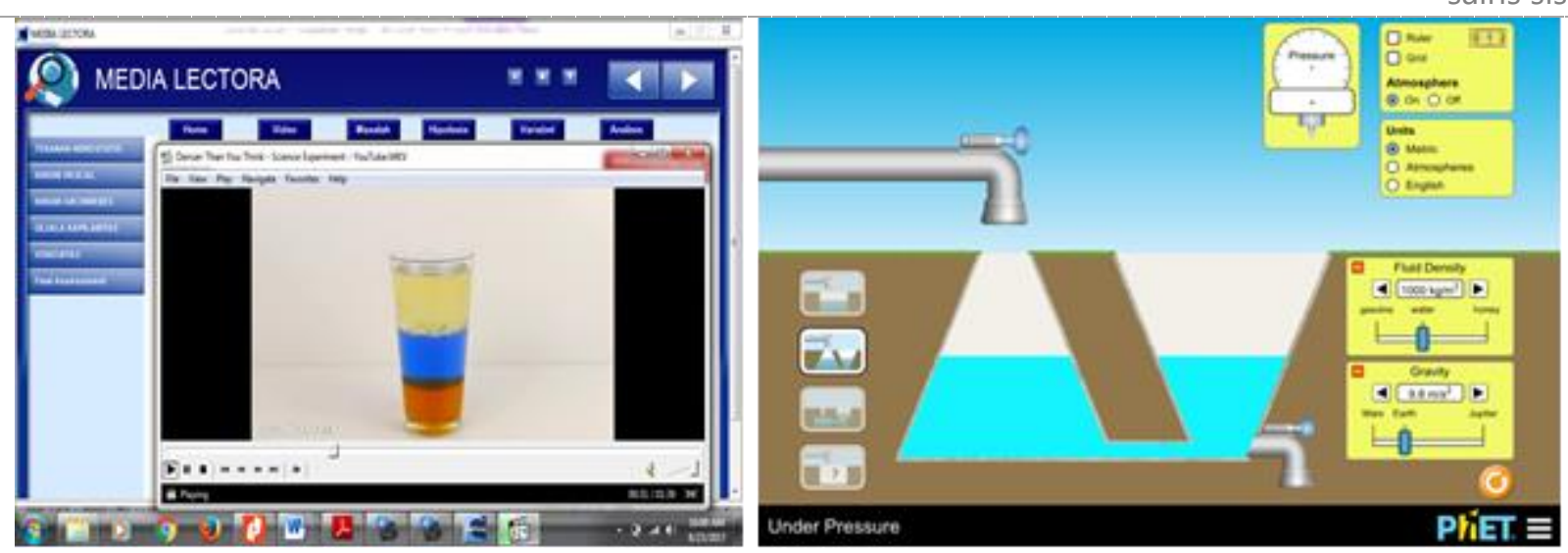

Gambar 1. (a) Video berkaitan dengan massa jenis zat cair dan (b) simulasi tekanan hidrostatis.

Validasi dilakukan oleh ahli media dan ahli materi untuk mengetahui kevalidan perangkat pembelajaran yang meliputi RPP, LKPD dan lembar kerja peserta didik serta Instrumen Lembar Pengamatan Keterampilan Pemecahan Masalah (KPS). Berdasarkan penilaian perangkat pembelajaran dan instrumen oleh validator, diperoleh persentasi penilaian terhadap perangkat pembelajaran GDM-IS dan instrumen keterampilan pemecahan masalah sebagai berikut.

Tabel 3. Persentasi Penilaian oleh pakar

\begin{tabular}{|c|c|c|c|c|}
\hline No & Produk & Aspek & $\begin{array}{l}\text { Rata-rata } \\
\text { persentasi }\end{array}$ & Kriteria \\
\hline \multirow[t]{4}{*}{1.} & \multirow{4}{*}{ RPP } & Format & 87,5 & Baik/Valid \\
\hline & & Materi & 81,25 & Baik/Valid \\
\hline & & Bahasa & 83,33 & Baik/Valid \\
\hline & & Metode dan Waktu & 91,67 & Baik/Valid \\
\hline \multirow[t]{4}{*}{2} & \multirow[t]{4}{*}{ LKPD } & Format & 87,5 & Baik/Valid \\
\hline & & Isi & 80,0 & Baik/Valid \\
\hline & & Bahasa dan Tulisan & 83,33 & Baik/Valid \\
\hline & & Kegunaan & 87,5 & Baik/Valid \\
\hline \multirow[t]{3}{*}{3} & \multirow[t]{3}{*}{ Media Pembelajaran } & Tampilan & 90,0 & Baik/Valid \\
\hline & & Manfaat & 87,5 & Baik/Valid \\
\hline & & Materi dan Penyajian & 81,25 & Baik/Valid \\
\hline \multirow[t]{3}{*}{4} & \multirow{3}{*}{$\begin{array}{l}\text { Lembar Pengamatan } \\
\text { KPS }\end{array}$} & Petunjuk & 93,75 & Baik/Valid \\
\hline & & Bahasa & 83,33 & Baik/Valid \\
\hline & & Isi & 81,25 & Baik/Valid \\
\hline
\end{tabular}

Berdasarkan penilaian validator pada semua aspek untuk RPP diperoleh rata-rata persentase 85,9\% yang menunjukkan bahwa RPP berada pada katagori baik/valid. Beberapa catatan diberikan oleh validator pada aspek materi berkaitan dengan tingkat kesulitan materi harus disesuaiakan dengan jenjang SMA. Untuk LKPD, diperoleh rata-rata persentase $84,58 \%$ yang menunjukkan bahwa LKPD tersebut berada pada katagori baik/valid dengan beberapa perbaikan dari segi bahasa dan penulisan serta isi dari LKPD. Untuk media pembelajaran (media simulasi dan video) diperoleh rata-rata persentase $86,25 \%$ yang menunjukkan bahwa media tersebut berada pada katagori baik/valid. Beberapa saran dari validator berkaitan dengan media ini adalah, sebaiknya video yang digunakan dibuat sendiri oleh peneliti dengan menggunakan bahasa yang mudah diterima oleh peserta didik. Sedangkan untuk lembar pengamatan Keterampilan Proses Sains diperoleh ratarata persentasi yaitu 86,11 yang berapa pada kategori valid. Berdasarkan hasil penilaian dan analisis dapat 
disimpulkan bahwa semua perangkat pembelajaran yang telah dikembangkan berada pada kategori layak untuk digunakan tetapi terlebih dahulu dilakukan perbaikan berdasarkan saran dari validator.

Setelah dilakukan perbaikan produk (perangkat pembelajaran) maka selanjutnya dilakukan tahapan uji coba. Perangkat pembelajaran selanjutnya digunakan oleh guru didalam kelas untuk 5 unit kegiatan. Selama pembelajaran berlangsung dilakukan pengamatan oleh 2 pengamat untuk memperoleh data keterampilan proses sains peserta didik. Data pengamatan keterampilan proses sains kemudian dianalisis dan dikategorikan berdasarkan aspek KPS untuk setiap unit kegiatan. Berikut adalahrata-rata persentasi KPS peserta didik untuk setiap aspek pada masing-masing unit kegiatan.

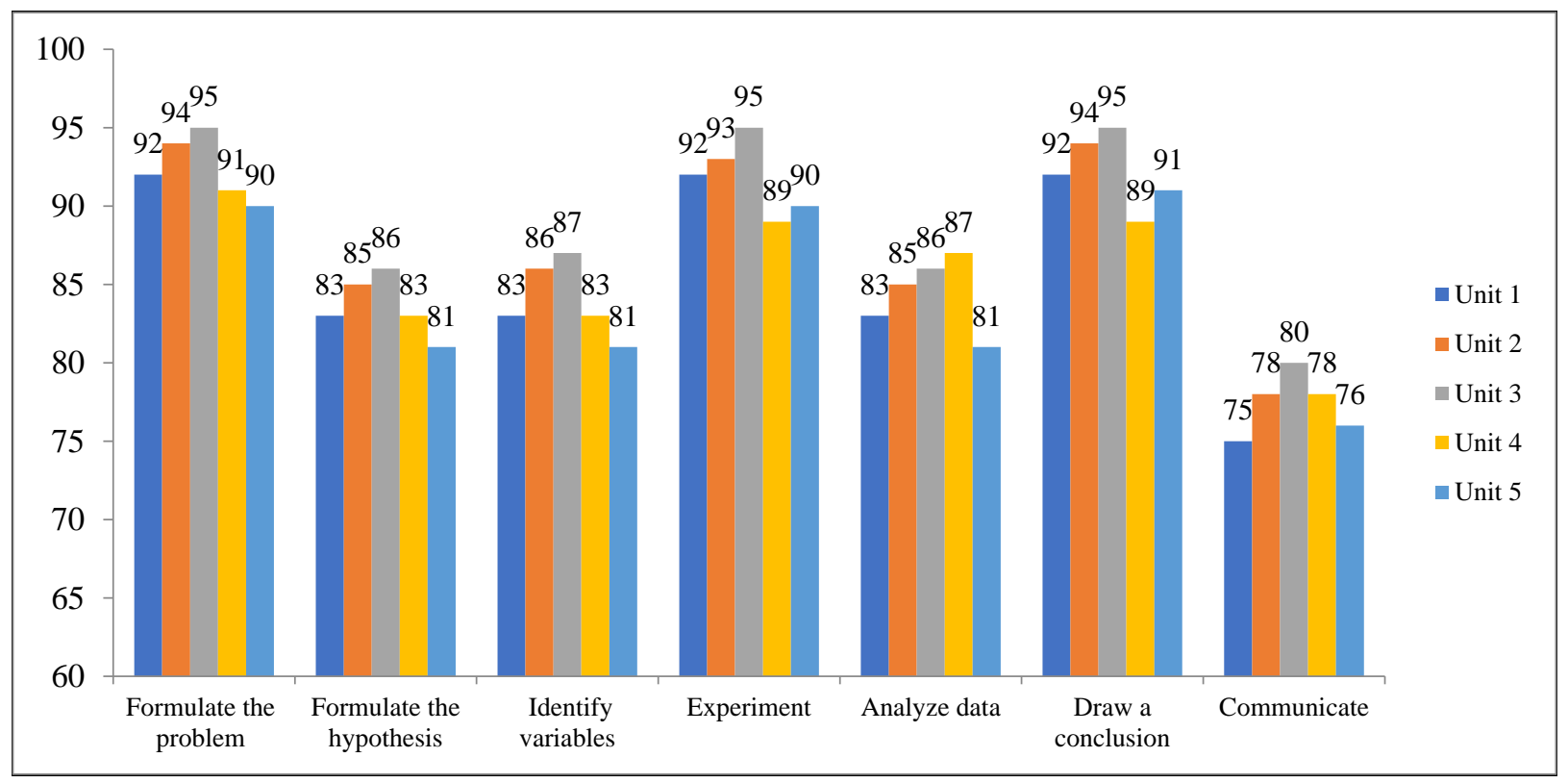

Gambar 2. Persentasi keterampilan proses sains untuk semua aspek

Keterampilan proses sains dikelompokkan kedalam beberapa aspek yaitu merumuskan masalah, membuat hipotesis, identifikasi variabel, melakukan eksperimen, analisis data, membuat kesimpulan dan komunikasi [4], [25], [26]. Secara umum rata-rata semua aspek di atas $85 \%$ yang menunjukkan bahwa penerapan perangkat pembelajaran ini membuat peserta didik lebih aktif dan meningkatkan keterampilan proses sainsnya. Dilihat dari unit kegiatan, persentasi tertinggi berada pada unit kegiatan 3 yang berkaitan dengan Tekanan Hidrostatis. Sedangkan persentasi terendah berada pada unit kegiatan 5 yaitu kapilaritas. Materi ini dianggap oleh peserta didik cukup sulit dan juga video yang digunakan berbahasa inggris sehingga peserta didik kesulitan menangkap penjelasan secara utuh. Sedangkan pada materi gaya hidrostatis, penjelasan dari video dan simulasi yang digunakan oleh peserta didik cukup jelas. Sedangkan dilihat dari aspek-aspek KPS. Aspek "merumuskan masalah" berada pada kategori sangat baik dengan persentasi diatas 90\%. Namun ketika peserta didik diminta untuk memberikan penjelasan berkaitan dengan apa yang telah mereka lakukan, masih banyak yang tidak percaya diri dan tidak mampu menguraikan temuan mereka. Namun aspek komunikasi ini masih berada pada kategori baik dengan persentasi rata-rata diatas $70 \%$.

Dari data penelitian di atas dapat dilihat bahwa ada pengaruh penerapan model pembelajaran discovery berbantuan video dan simulasi pemberlajaran terhadap keterampilan proses sains siswa. Pada model pembelajaran discovery ini siswa diberi kesempatan melakukan ekperimen untuk menemukan jawaban dari permasalahan yang mereka temukan serta menguji hipotesis yang telah mereka buat yang diungkapkan dalam lembar kerja peserta didik [5], [6], [27]. Dalam pelaksanaan ekperimen secara berkelompok peserta didik melakukan pengamatan berdasarkan arahan dan petunjuk dari LKPD dan hasil pengamatan itu kemudian dicatat dan dianalisis sehingga peserta didik menemukan sendiri konsep sesuai dengan tujuan pembelajaran[25], [26]. Pembelajaran discovery terbimbing dengan pemanfaatan media simulasi komputer terbukti melatih peserta didik untuk mengembangkan keterampilan proses sains sehingga hakikat sains sebagai proses dan produk dalam pembelajaran fisika dapat terlaksana secara maksimal [24]. 
Konsep pembelajaran pada materi fluida statis dengan model penemuan terbimbing didukung oleh simulasi interaktif dan video memiliki kelebihan dan kekurangan. Kelebihan model ini adalah membantu peserta didik dalam mengingat dan menggunakan rumus fisika karena peserta didik menemukan sendiri rumus tersebut sesuai pengarahan guru dan lembar kerja dan mereka juga lebih aktif [27]. Sedangkan simulasi interaktif dan video dapat digunakan sebagai media pembelajaran yang interaktif, efektif dan efisien baik di luar jam sekolah maupun digunakan pada saat kegiatan belajar mengajar berlangsung [24]. Peserta didik dapat mereview materi yang telah disampaikan oleh guru melalui media, sedangkan guru dituntut untuk selalu mengembangkan materi dan soal agar peserta didik tidak bosan untuk selalu menggunakan media ini. Dengan kondisi tersebut peserta didik akan semakin memperkuat penguasaannya terhadap materi pembelajaran dan peserta didik menjadi lebih aktif. Selain itu, dengan penerapan model pembelajaran penemuan terbimbing peserta didik akan lebih termotivasi dalam mengikuti pembelajaran, pembelajaran yang bermakna akan membuat mereka lebih teransang dan daya ingat terhadap konsep yang telah mereka pelajari sangat tinggi [28], [29].

Hasil penelitian ini sesuai dengan pendapat Bruner bahwa Model Discovery Learning merupakan model yang sesuai dengan pencarian pengetahuan secara aktif oleh manusia, dan dengan sendirinya memberikan hasil yang terbaik [5]. Guru hendaknya mendorong siswa untuk memecahkan masalah yang dihadapinya atau menyelesaikannya sendiri dalam kelompoknya, bukan mengajari mereka jawaban dari masalah yang dihadapi [6], [7]. Guru dalam melaksanakan pembelajaran hendaknya tidak langsung memberikan solusi taktis, tetapi lebih pada pengarahan. Hal ini membantu menstimulasi pemikiran siswa dengan membuat rumusan masalah, memberikan pilihan kepada siswa untuk dapat mengkonstruksi akhirnya pemikirannya dapat menemukan solusi bagi masalahnya sendiri. Model Discovery Learning menekankan pada penemuan konsep atau prinsip yang sebelumnya tidak diketahui [6], [30], [31]. Siswa diberikan stimulus berupa fenomena atau masalah yang sengaja direkayasa oleh guru untuk meningkatkan kemampuan berpikir kreatifnya dalam menemukan solusi dari masalah yang diajukan [4]. Penyajian bahan ajar pada model Discovery Learning mengarahkan siswa untuk melakukan berbagai kegiatan seperti merumuskan masalah, mengidentifikasi masalah, mengumpulkan data, menganalisis data dan membuat kesimpulan. Cara penyajian bahan ajar tersebut menjadikan pembelajaran lebih bermakna, karena siswa dapat menemukan konsep dengan mengkonstruksi sendiri pengetahuan yang ingin diketahuinya. Pengetahuan yang diperoleh melalui learning discovery yang dipadukan dengan media simulasi yang interaktif dan menarik dapat meningkatkan penalaran dan kemampuan berpikir bebas serta meningkatkan keterampilan kognitif untuk menemukan dan memecahkan masalah [1], [7], [10], [19], [31].

\section{Kesimpulan}

Berdasarkan hasil analisis dan pembahasan data, dapat disimpulkan bahwa: (1) perangkat pembelajaran dengan Guided Discovery Model Assisted Interactive Simulation (GDM-IS) yang dihasilkan dalam penelitian ini memenuhi kriteria valid dan layak digunakan dalam uji coba; (2) keterampilan proses sains siswa berdasarkan observasi ahli berada di atas $80 \%$ yang menunjukkan bahwa penggunaan GDM-IS berdampak positif.

Saran yang dapat diambil dari hasil penelitian ini adalah: (1) Perangkat pembelajaran yang telah dikembangkan sebaiknya dapat digunakan sebagai pedoman dalam penyelenggaraan pembelajaran materi fluida statik di instansi lain agar suasana pembelajaran fisika lebih variatif dan menyenangkan karena diharapkan. Kurikulum 2013; (2) pengembangan perangkat pembelajaran tidak hanya dikembangkan pada materi fluida statis, tetapi juga pada materi lain; (3) Video yang digunakan harus direkam sendiri, jangan menggunakan video dari youtube.com apalagi menggunakan bahasa Inggris.

\section{Kepustakaan}

[1] S. Ahmad and D. A. Bunga, "Pengembangan Media Simulasi Interaktif Berbasis Web untuk Meningkatkan Aktivitas Belajar Peserta Didik," Pros. Pertem. Ilm. XXIXHFI Jateng DIY, no. April, pp. 192-195, 2015.

[2] A. Yani, "Pengaruh Media Model Hybrid Berbasis Web Whanced Course Terhadap Hasil Belajar Fisika," J. Sains dan Pendidik. Fis., vol. 13, no. 3, pp. 224-230, 2017. 
[3] N. K. N. Dewi, I. I. W. Suwatra, I. W. Widiana, and J. Pgsd, "Analisis Diskrepansi Pembelajaran Kurikulum 2013 Berdasarkan Permendikbud Nomor 65 Tahun 2013 Sd Negeri 3 Banjar Jawa,” Mimb. PGSD Undiksha, vol. 3, no. $1,2015$.

[4] R. P. Saputro, W. Wasis, and T. Koestiari, "Pengembangan Perangkat Pembelajaran Fisika Model Discovery Learning Untuk Meningkatkan Hasil Belajar Dan Keterampilan Berpikir Kreatif," JPPS (Jurnal Penelit. Pendidik. Sains), vol. 5, no. 1, p. 693, 2017, doi: 10.26740/jpps.v5n1.p693-702.

[5] I. WIDIADNYANA, M. Sadia, and M. Suastra, "Pengaruh Model Discovery Learning Terhadap Pemahaman Konsep Ipa Dan Sikap Ilmiah Siswa Smp,” J. Pendidik. dan Pembelajaran IPA Indones., vol. 4, no. 2, 2014.

[6] I. M. Putrayasa, H. Syahruddin, and I. G. Mergunayasa, "Pengaruh Model Pembelajaran Discovery Learning Dan Minat Belajar Terhadap Hasil Belajar Ipa Siswa," J. Mimb. PGSD Univ. Pendidik. Ganesha, vol. 2, no. 1, pp. 1$11,2014$.

[7] S. Juhri, "Penerapan Model Discovery Learning Untuk Meningkatkan Hasil Belajar Siswa Kelas Ix Pada Pembelajaran Ipa,” BIO Educ. (The J. Sci. Biol. Educ., vol. 5, no. 2, pp. 371-380, 2020, doi: 10.31949/be.v5i2.2597.

[8] R. Hidayat, L. Hakim, L. Lia, P. Fisika, and F. Keguruan, " $x=85,00$," vol. 7, no. 2, pp. 97-104, 2019, doi: 10.20527/bipf.v7i2.5900.

[9] A. Swandi, B. D. Amin, S. Viridi, and F. D. Eljabbar, "Harnessing technology-enabled active learning simulations (TEALSim) on modern physics concept," J. Phys. Conf. Ser., vol. 1521, no. 2, 2020, doi: 10.1088/17426596/1521/2/022004.

[10] B. D. Amin and A. Mahmud, "The Development of Physics Learning Instrument Based on Hypermedia and Its Influence on the Student Problem Solving Skill," J. Educ. Pract., vol. 7, no. 6, pp. 22-28, 2016.

[11] P. Magister, P. Fisika, D. Fisika, U. N. Makassar, and D. P. Fisika, " 21 th century physics learning in senior high school through interactive computer simulation to enhance students achievement," vol. 3, no. 1, pp. 130-135, 2018.

[12] P. Palloan and A. Swandi, "Development of learning instrument of active learning strategy integrated with computer simulation in physics teaching and learning on makassar state university," J. Phys. Conf. Ser., vol. 1157, no. 3, 2019, doi: 10.1088/1742-6596/1157/3/032016.

[13] Gunawan, A. Harjono, and H. Sahidu, "Pengembangan Model Laboratorium Virtual Berorientasi Pada Kemampuan Pemecahan Masalah Bagi Calon Guru Fisika," Pros. Semin. Nas. Fis. dan Pendidik. Fis., vol. 6, no. 1, pp. 232-237, 2015.

[14] A. Swandi, S. H. Nurul, and Irsan, "Pengembangan Media Pembelajaran Laboratorium Virtual untuk Mengatasi Miskonsepsi Pada Materi Fisika Inti di SMAN 1 Binamu, Jeneponto (Halaman 20 s.d. 24),” vol. 18, no. 52, pp. 20-24, 2015, doi: 10.22146/jfi.24399.

[15] N. F. Hassan, S. Puteh, and R. Buhari, "Student Understanding Through the Application of Technology Enabled Active Learning in Practical Training," Procedia - Soc. Behav. Sci., vol. 204, no. November 2014, pp. 318-325, 2015, doi: 10.1016/j.sbspro.2015.08.158.

[16] R. S. Shieh, "The impact of technology-enabled active learning (TEAL) implementation on student learning and teachers' teaching in a high school context," Comput. Educ., vol. 59, no. 2, pp. 206-214, 2012, doi: 10.1016/j.compedu.2012.01.016.

[17] R. S. Shieh, "The impact of technology-enabled active learning on student performance, gender and achievement level," CSEDU 2010 - 2nd Int. Conf. Comput. Support. Educ. Proc., vol. 2, pp. 420-425, 2010, doi: $10.5220 / 0002783504200425$.

[18] D. Domin and D. S. Domin, "A Review of Laboratory Instruction Styles A Review of Laboratory Instruction Styles," no. MARCH 1999, 2015, doi: 10.1021/ed076p543.

[19] B. D. Amin, A. Haris, and A. Swandi, "Implementation of Physics Learning Based on Hypermedia To Enhance Student'S Problem Solving Skill,” Int. J. Teach. Educ., vol. VII, no. 2, pp. 1-11, 2019, doi: 10.20472/te.2019.7.2.001.

[20] P. Penelitian dalam Menunjang Percepatan Pembangunan Berkelanjutan di Indonesia, B. Dara Amin, A. Azis, and A. Swandi, "Identifikasi Potensi Penggunaan Bahan Ajar Fisika Berbasis Simulasi Komputer yang Interaktif dengan Model Inkuiri Terbimbing pada Konsep Abstrak: Studi Literatur and Survey," Semin. Nas. LP2M UNM, vol. 0, no. 0, pp. 386-399, 2019.

[21] A. Suwito and D. Trapsilasiwi, "Pengembangan Model Pembelajaran Matematika Smp Kelas Vii Berbasis Kehidupan Masyarakat Jawara (Jawa Dan Madura) Di Kabupaten Jember," JIPM (Jurnal Ilm. Pendidik. Mat., vol. 4, no. 2, p. 79, 2016, doi: $10.25273 /$ jipm.v4i2.841.

[22] I. Yusuf and Subaer, "Pengembangan perangkat pembelajaran fisika berbasis media laboratorium virtual pada materi dualisme gelombang partikel di sma tut wuri handayani Makassar," J. Pendidik. IPA Indones., vol. 2, no. 2, pp. 189-194, 2013, doi: 10.15294/jpii.v2i2.2722.

[23] I. Agustina, D. Astuti, R. A. Sumarni, and D. L. Saraswati, "Pengembangan Media Pembelajaran Fisika Mobile Learning berbasis Android," vol. 3, pp. 57-62, 2017. 
[24] Irfan Yusuf dan Sri Wahyu Widyaningsih, "Laboratorium Virtual Terhadap Keterampilan Proses sains dan persepsi mahasiswa," Inov. Pendidik. Fis., vol. 6, no. 1, pp. 18-28, 2018.

[25] A. Hasanah and L. Utami, "Pengaruh Penerapan Model Problem Based Learning Terhadap Keterampilan Proses Sains Siswa,” J. Pendidik. Sains, vol. 5, no. 2, pp. 56-64, 2017.

[26] E. Susanti and M. Jamhari, "Pengaruh Model Pembelajaran Discovery Learning Terhadap Keterampilan Sains Dan Hasil Belajar Siswa Kelas Viii Tentang Ipa Smp Advent Palu,” J. Sains dan Teknol., vol. 5, no. 3, pp. 36-41, 2016.

[27] K. Arafah, "The Effect of Guided Discovery Method and Learning Interest on Students' Understanding of Physics Concepts," J. Pendidik. Fis., vol. 8, no. 2, pp. 147-154, 2020, doi: 10.26618/jpf.v8i2.3259.

[28] D. Eniyati, "Penerapan Model Discovery Learning Pada Pembelajaran Fisika Tentang Fluida Untuk Meningkatkan Hasil Belajar Peserta Didik Kelas Xi Ipa- B Sman 5 Kota Bogor,” Educ. J. Teknol. Pendidik., vol. 3, no. 1, p. 119, 2018, doi: 10.32832/educate.v3i1.999.

[29] N. Isnawati, A. Harjono, and I. W. Gunada, "Hasil Belajar Fisika Dengan Model Discovery Learning," Penelit. dan Pembelajaran Fis. Indones., no. 1, pp. 11-15, 2020.

[30] H. Hanafi, "The Effect of Discovery Learning Method Application on Increasing Students' Listening Outcome and Social Attitude," Din. Ilmu, vol. 16, no. 2, p. 291, 2016, doi: 10.21093/di.v16i2.552.

[31] M. F. Al Hakim, S. Sariyatun, and S. Sudiyanto, "Constructing Student`s Critical Thinking Skill through Discovery Learning Model and Contextual Teaching and Learning Model as Solution of Problems in Learning History," Int. J. Multicult. Multireligious Underst., vol. 5, no. 4, p. 175, 2018, doi: 10.18415/ijmmu.v5i4.240. 